\title{
A NEW SPECIES OF QUESTIERIELLA FROM TAMIL NADU
}

\author{
V.B. Hosagoudar ${ }^{1}$, S. Madhavan ${ }^{2}$, V. Dhivaharan ${ }^{2}$ and G. Sangeetha ${ }^{2}$
}

\begin{abstract}
${ }^{1}$ Tropical Botanic Garden and Research Institute, Palode, Thiruvananthapuram 695562, Kerala, India
${ }^{2}$ Department of Microbiology, Sengamala Thayaar Educational Trust Women's College, Mannargudi, Tamil Nadu 614001, India Email: ${ }^{1}$ vbhosagoudar@ rediffmail.com
\end{abstract}

plus web supplement of 1 page

\begin{abstract}
Questieriella toddaliae sp. nov. collected on Toddalia sp. from Kodaikanal has been described and illustrated as a new species.

KEYWORDS

Fungus, India, new species, Questieriella toddaliae, Tamil Nadu

\section{Abbreviations}

HCIO - Herbarium Cryptogamae Indiae Orientalis, New Delhi; TBGT - Tropical Botanic Garden, Thiruvananthapuram
\end{abstract}

During a survey of foliicolous fungi in the montane forests of Kodaikanal, the authors came across a plant infected with a black mildew fungus. Microscopic observation of the fungus revealed falcate conidia borne on an appressoriate brown mycelium, which are the characters of the form genus Questieriella, a synanamorph of the genus Schiffnerula. The teleomorphic genus Schiffnerula includes four synanamorphs, namely, Questieriella, Mitteriella, Digitosarcinella and Sarcinella. The genus Questieriella differs from other form genera in having falcate 3 -septate falcate conidia.

\section{QUESTIERIELLA TODDALIAE sp. nov.}

(Fig. 1, Image $1^{\mathrm{w}}$ )

\section{Material examined}

Holotype: 18.vi.2006, on leaves of Toddalia asiatica (L.) Lam. (Rutaceae), Mathikettan shola, Kodaikanal, Tamil Nadu, coll. G. Sangeetha, HCIO 47675.

Isotype: TBGT 2697.

\section{Diagnosis}

Coloniae amphigenae, tenues, ad $2 \mathrm{~mm}$ diam. Confluentes. Hyphae rectae vel subrectae, opposite, alternate vel irregulariter acuteque vel laxe ramosae, laxe reticulatae, cellulae 14-24 x 4-8um. Appressoria alternata, dispersa, unicellularis, ovala vel globosa, integra vel leniter angularis, 9-13

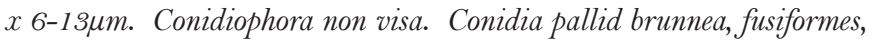
curvula, 3-septata, leniter constrictae ad septata, 24-37 x 11-184m, attenuatae ad ambi apicem.

Colonies amphigenous, thin, up to $2 \mathrm{~mm}$ in diameter, confluent. Hyphae straight to substraight, branching opposite, alternate to irregular at acute to wide angles, loosely reticulate, cells 14-24 x 4-8 $\mu \mathrm{m}$. Appressoria alternate, scattered, unicellular, oval to

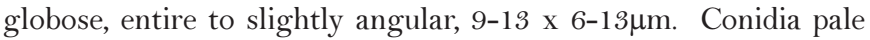

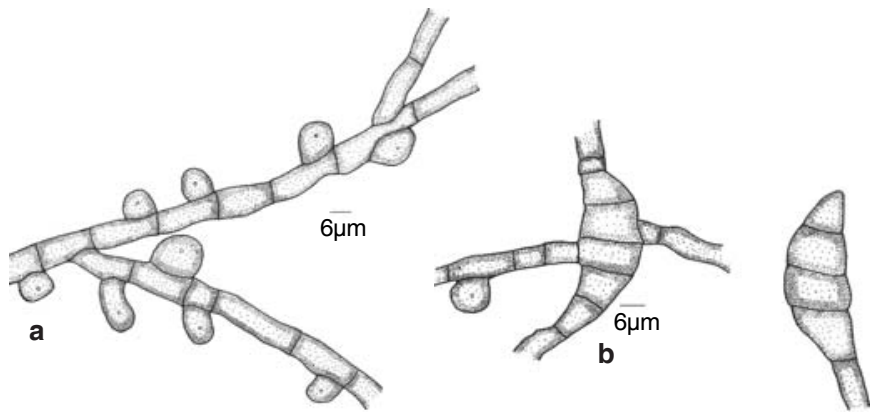

Figure 1. Germinating 3-septate conidia produced appressoriate mycelium

brown, fusiform, curved, 3-septate, slightly constricted at the septa, distal cells attenuated, 24-37 x 11-18 $\mu \mathrm{m}$.

\section{Remarks}

Schiffnerula toddaliae Hansf. is known on this host from Uganda with Questieriella anamorph (Hansford, 1941). Clypeolella toddaliae Hansf. known on T. aculeate from Uganda has only teleomorphic state and has been made synonymous to Schiffnerula toddaliae Hansf. (Hughes, 1983, 1987; Hosagoudar, 2003).

The present collection appears to be the synanamorph of the genus Schiffnerula toddaliae Hansf. but in absence of the teleomorphs, it is preferred to accommodate it in a distinct entity. Hence, it is placed under a new species.

\section{REFERENCES}

Hansford, C.G. (1941). Contribution towards the fungus flora of Uganda - II Some Uganda Ascomycetes. Proceedings of the Linnean Society of London 194041: 1:4-52.

Hansford, C.G. (1944). Contribution towards the fungus flora of Uganda - VI. New records. Proceedings of the Linnean Society of London 156: 102-124.

Hosagoudar, V.B. (2003). The genus Schiffnerula and its synanamorphs. Zoos' Print Journal 18: 1071-1078.

Hughes, S.J. (1983). Five species of Sarcinella from North America, with a note on Questieriella n. gen., Mitteriella, Endophragmiopsis, Schiffnerula, and Clypeolella. Canadian Journal of Botany 61: 1727-1767.

Hughes, S.J. (1987). Pleomorphy in some hyphopodiate fungi., pp.103-139. In: Sugiyama (ed.). Pleomorphic Fungi. The Diversity and its Taxonomic Implications. Kodansa \& Elsevier, Tokyo.

\section{ACKNOWLedgement}

We thank Dr. S. Ganeshan, Director, TBGRI, Palode for the facilities.

Comparative account with the allied species

\begin{tabular}{|c|c|c|}
\hline Name of the species & Conidiophores & Conidia \\
\hline $\begin{array}{l}\text { Schiffnerula toddaliae Hansf. } \\
\text { Questieriella-form }\end{array}$ & $\begin{array}{l}\text { Unicellular, unilateral,similar to } \\
\text { appressoria }\end{array}$ & Falcate, olivaceous brown, acute towards both ends, 3-septate, $35-40 \times 10-12 \mu \mathrm{m}$ \\
\hline Questieriella toddaliae sp. nov. & Conidiophores not distinct & $\begin{array}{l}\text { Conidia pale brown, fusiform, curved, 3-septate, slightly constricted } \\
\text { at the septa, distal cells attenuated, } 24-37 \times 11-18 \mu \mathrm{m}\end{array}$ \\
\hline
\end{tabular}

${ }^{\mathrm{w}}$ See Image $1^{\mathrm{w}}$ in the web supplement at www.zoosprint.org 